DANUTA JANCZEWSKA

Społeczna Wyższa Szkoła Przedsiębiorczości i Zarządzania w Łodzi

\title{
Proces kształtowania potencjału innowacyjnego przedsiębiorstw z grupy MŚP w sektorze konstrukcji stalowych w warunkach konkurencji na rynku Unii Europejskiej
}

Przedsiębiorstwa z grupy MŚP (małe i średnie przedsiębiorstwa) stanowią większość przedsiębiorstw funkcjonujących w polskiej rzeczywistości gospodarczej. Zmiany w przedsiębiorstwach polegające na szybszym wdrażaniu innowacji w postaci nowych rozwiązań technicznych, technologicznych, organizacyjnych wpływają na rozwój i konkurencyjność tych przedsiębiorstw, konkurencyjność branży, a tym samym całej gospodarki w okresie integracji z gospodarką Unii Europejskiej i globalizacji. Zatem poznanie przyczyn dynamiki zmian innowacyjnych oraz ich struktury w przedsiębiorstwach MŚP pozwoli na wskazanie grup czynników wpływających na proces innowacyjny - ważnych z punktu widzenia samych przedsiębiorstw oraz z perspektywy branży, sektora i makrogospodarki.

Małe i średnie przedsiębiorstwa w Polsce mają znaczący wpływ na kształt i wyniki gospodarki. Rozwój sektora MŚP nastąpił w okresie transformacji systemowej, po roku 1989, i obecnie możemy rozpatrywać okres dwudziestu lat rozwoju tej grupy przedsiębiorstw (Wojnicka, Klimczak 2006). Wielkość przedsiębiorstwa MŚP oraz jego potencjał może decydować o zasięgu działania i relacjach z otoczeniem; natomiast liczba podmiotów małej i średniej wielkości w istotny sposób kształtuje strukturę gospodarki oraz wielkość PKB. W literaturze polskiej okres od roku 1989 do chwili obecnej jest prezentowany jako pewien cykl życia sektora MŚP, z uwzględnieniem wyraźnych jego faz (Żołnierski 2009), wśród których zaznaczają się następujące okresy:

Faza I - wstępna faza rozwoju przedsiębiorczości - datuje się jeszcze przed rokiem 1989. Jej początek nastapił w latach gospodarki centralnie planowanej.

Faza II - lata 1989-1994, w której dynamicznie wzrosła liczba przedsiębiorstw z grupy MŚP oraz ich udział w tworzeniu PKB. Początek okresu transformacji systemowej sprzyjał powstawaniu nowych przedsiębiorstw, a ich liczba w roku 1994 przekroczyła 2 miliony podmiotów.

Faza III - faza samoregulacji rynkowej, charakteryzująca się stabilizacją tempa wzrostu liczby podmiotów. Opinie o kontynuacji zjawisk w tej fazie cyklu życia sektora MSP nie do końca obrazują zjawiska zachodzące w sektorze MŚP - ze względu na tendencje, które pojawiły się po roku 2000. Można po roku 2000 wyróżnić kolejne charakterystyczne okresy i obecnie - przyjmując rok 1999 jako rok bazowy (100\%) - wskazać na ukształtowanie się kilku nowych wyraźnych tendencji w strukturze przedsiębiorstw w Polsce. 
Faza IV - w latach 2000-2002 odnotowuje się stały spadek liczby przedsiębiorstw zatrudniających powyżej 250 pracowników. Dynamika rozwoju przedsiębiorstw w tym okresie przybiera wskazania charakterystyczne dla określonej grupy przedsiębiorstw, co przedstawia ryc. 1. Liczba przedsiębiorstw zatrudniających do 9 pracowników w latach 2000-2002 wzrosła o 20\%, dynamika wzrostu liczby przedsiębiorstw zatrudniających 10-49 osób zamyka się w zakresie $12 \%$, a przedsiębiorstw dużych - na poziomie $8 \%$.

Faza V - w okresie 2002-2004, w którym to czasie nastąpiło utrwalenie dynamiki rozwoju przedsiębiorstw zatrudniających do 9 osób, w grupie przedsiębiorstw małych nastąpił niewielki wzrost - na poziomie $2-3 \%$, natomiast $w$ grupie przedsiębiorstw średnich wystąpił wyraźny spadek dynamiki poniżej poziomu bazowego z roku 1999 do poziomu 98\%. Jednak największe zmiany nastąpiły w tym okresie w grupie przedsiębiorstw dużych - gdzie liczba przedsiębiorstw obniżyła się do poziomu 72\% w odniesieniu do roku bazowego 1999.

W okresie 1999-2007 należy zauważyć wyraźne dynamiczne zmiany (wzrost) struktury i liczby przedsiębiorstw MŚP w Polsce oraz spadek liczby przedsiębiorstw dużych, co przedstawiono na ryc. 1 .

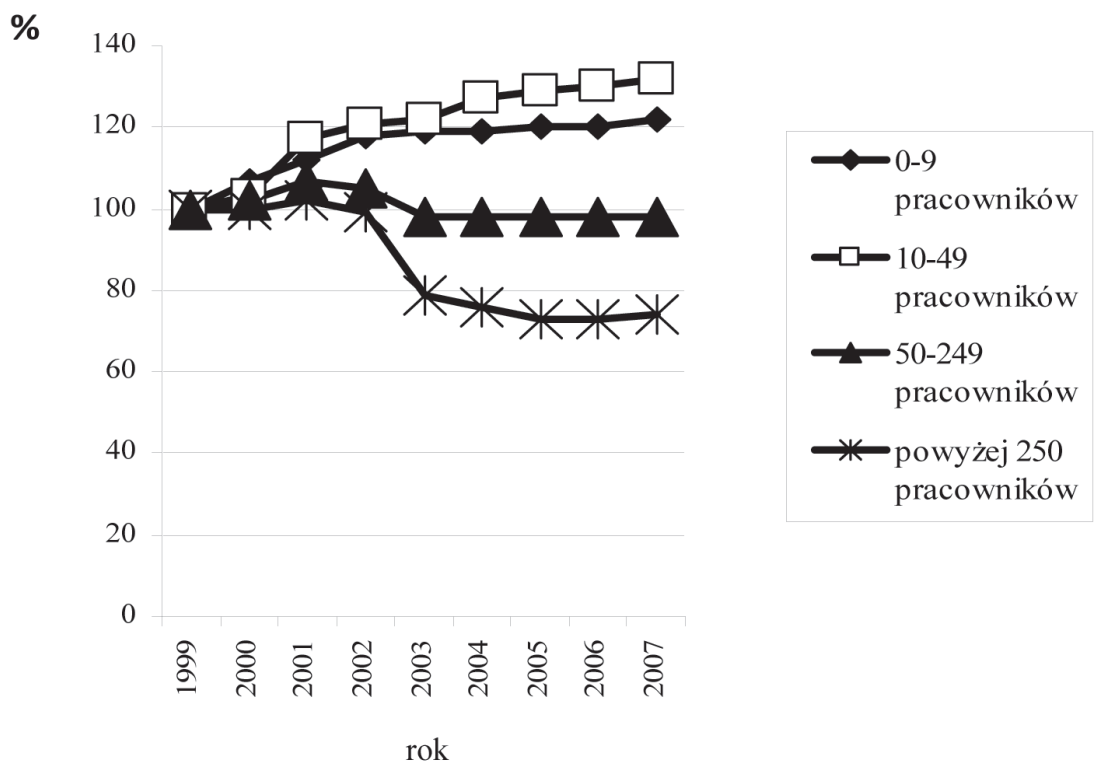

Ryc. 1. Dynamika rozwoju liczby przedsiębiorstw w Polsce w latach 1999-2007.

$$
\text { Rok } 1999=100 \%
$$

Źródło: M. Koszarek, G. Milewski, M. Rybacka, S. Szultka, Analiza czynników konkurencyjności sektora MŚP w Polsce, Instytut Badań nad Gospodarką Rynkową, Gdańsk 2008

Obecnie przedsiębiorstwa z grupy MŚP zdecydowanie dominują w strukturze przedsiębiorstw, stanowiąc 99\% ogólnej liczby zarejestrowanych podmiotów gospodarczych (Balcerowicz 2009). Na koniec 2008 roku w systemie REGON zarejestrowanych było 3757,1 tys. podmiotów gospodarki narodowej (bez osób prowadzących indywidualne gospodarstwa w rolnictwie) - o 71 tys. więcej niż na koniec roku 2007. Spośród zarejestro- 
wanych podmiotów 124,5 tys. należało do sektora publicznego (było to aż o 10,7\% mniej niż w roku 2007), zaś 3632,6 tys. do sektora prywatnego (wzrost o 2,4\%). Liczba przedsiębiorstw państwowych zmniejszyła się z 572 do 363 . Z kolei liczba podmiotów zarejestrowanych jako osoby fizyczne wyniosła 2845 tys. (wzrost w stosunku do ubiegłego roku o 2,1\%).

Badanie struktury geograficznej aktywnych w 2007 roku przedsiębiorstw wykazuje, że największa ich liczba znajduje się w czterech największych województwach: mazowieckim, śląskim, wielkopolskim oraz małopolskim. Z kolei cztery najmniejsze województwa (lubuskie, opolskie, świętokrzyskie oraz podlaskie) grupowały zaledwie $10 \%$ firm. Przedsiębiorstwa duże koncentrowały się w dwóch województwach: mazowieckim oraz śląskim - w tym pierwszym siedzibę miało 23\% firm, w drugim 13\%. Można zatem wskazać na pewne geograficzne strefy koncentracji przedsiębiorstw - nie tylko w największych województwach, ale również w obszarach, które tradycyjnie miały charakter przemysłowy.

W porównaniu z rokiem 2006 liczba aktywnych przedsiębiorstw wzrosła o 3,5\%, w tym najbardziej w województwach: kujawsko-pomorskim, dolnośląskim, mazowieckim oraz podlaskim. Spadek liczby firm miał miejsce w województwie śląskim, warmińsko-mazurskim oraz zachodniopomorskim. W strukturze funkcjonujących w Polsce przedsiębiorstw aktywnych, to jest prowadzących działalność, dominują mikroprzedsiębiorstwa, zatrudniające od 0 do 9 pracowników. W 2007 roku stanowiły one 95\% aktywnych przedsiębiorstw. Firmy małe (od 10 do 49 pracowników) to 4,2\% firm, zaś niecały procent stanowią firmy średnie (od 50 do 249 pracowników). Znikomą część ogółu firm (0,14\%) stanowią przedsiębiorstwa duże (zatrudniające co najmniej 250 pracowników). Struktura firm z grupy MŚP została pokazana na ryc. 2 .

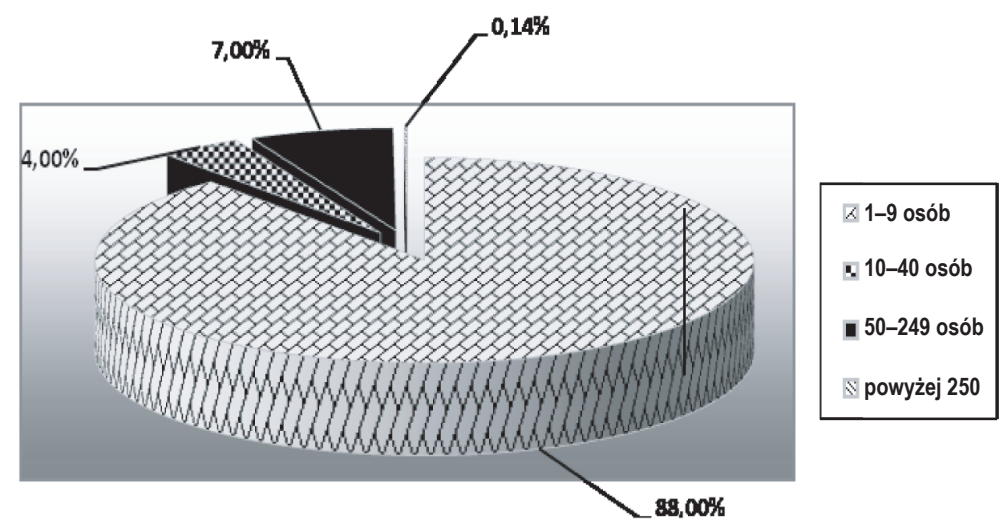

Ryc. 2. Struktura przedsiębiorstw w Polsce w roku 2007

Źródło: Raport o stanie sektora MSP w Polsce, Warszawa, 8 czerwca 2009 r., PARP

Przedsiębiorstwa z grupy MŚP uczestniczą w wytwarzaniu dochodu narodowego, jednak ich udział nie odpowiada strukturze przedsiębiorstw w gospodarce. Na przestrzeni ostatnich 5 lat udział sektora MŚP w tworzeniu PKB pozostaje na zbliżonym poziomie ${ }^{1}$ i wynosi 47,4\%, w tym: przedsiębiorstw mikro - 30,1\%, przedsiębiorstw małych $-7,3 \%$,

\footnotetext{
${ }^{1}$ Raport o stanie sektora MSP w Polsce, Warszawa, 8 czerwca 2009 r., PARP - Konferencja „Sektor MSP - stan obecny i perspektywy rozwoju", Warszawa 2009.
} 
przedsiębiorstw średnich $-10 \%$. Duże przedsiębiorstwa, których jest niewiele ponad 5 tys., wytwarzają ponad $50 \%$ PKB.

W ujęciu branżowym i gałęziowym przedsiębiorstwa z grupy MŚP największy wkład w PKB wykazują w branżach: działalność produkcyjna - 34\%, handel i naprawy $-26 \%$, obsługa nieruchomości - $26 \%$.

Duża liczba przedsiębiorstw MŚP może świadczyć o występowaniu pomiędzy nimi działań konkurencyjnych w danej branży czy gałęzi gospodarki. Nie są to jednak działania podobne do tych prowadzonych przez firmy duże lub koncerny międzynarodowe - dysponujące dużym potencjałem finansowym oraz posiadające organizacyjne i personalne możliwości podnoszenia konkurencyjności na rynku.

Badania własne dotyczące sektora konstrukcji stalowych w Polsce wykazały, że procesy w zarządzaniu firmą MSP, w tym zarządzanie relacjami z rynkiem i konkurentami - wykazują pewne różnice w porównaniu z firmami dużymi ${ }^{2}$. Powstaje zatem pytanie, jakie elementy działalności przedsiębiorstw z grupy MSP mogą charakteryzować i wyróżniać poszczególne grupy przedsiębiorstw w dziedzinie zarządzania, marketingu, budowy strategii czy konkurencyjności.

Porównanie wybranych obszarów działalności poszczególnych rodzajów przedsiębiorstw pozwala na zidentyfikowanie pewnych grup problemów, wśród których na szczególną uwagę zasługuje podejście do innowacji. Analiza danych GUS wskazuje na pewne niedostateczne badania mikroprzedsiębiorstw, zatrudniających do 9 osób $^{3}$. Brak jest także badań sektorowych przedsiębiorstw MŚP, jak również metodyki odpowiadającej specyfice działalności gospodarczej. Badania udziału przedsiębiorstw przemysłowych i usługowych wdrażających innowacje procesowe i produktowe w latach 2004-2006 prowadzone przez PARP (Żołnierski 2008) nie pozwalają na uzyskanie pełnego obrazu innowacyjności przedsiębiorstw MŚP wdrażających innowacje procesowe i produktowe, co przedstawia tabela 1.

Tab. 1. Udział przedsiębiorstw przemysłowych i usługowych wdrażających innowacje procesowe i produktowe w latach 2004-2006 w ogólnej liczbie przedsiębiorstw w sektorze MŚP (\%)

\begin{tabular}{|l|c|c|}
\hline \multirow{2}{*}{ Liczba zatrudnionych } & \multicolumn{2}{|c|}{ Udział } \\
\cline { 2 - 3 } & przemysł & usługi \\
\hline $0-9$ & brak danych & brak danych \\
\hline $10-49$ & 13,9 & 16,9 \\
\hline $50-249$ & 37,4 & 34,8 \\
\hline powyżej 249 & 65,5 & 53,5 \\
\hline
\end{tabular}

Źródło: Opracowanie własne na podstawie Działalność innowacyjna przedsiębiorstw w latach 2004-2006, GUS, Warszawa 2008

\footnotetext{
${ }^{2}$ Szerzej na temat badań firm w sektorze konstrukcji stalowych w „Wykorzystanie strategii innowacyjnych opartych na kształtowaniu społeczeństwa informacyjnego w procesie poprawy konkurencyjności przedsiębiorstwa”, referat na konferencji „Rola przedsiębiorczości w kształtowaniu społeczeństwa informacyjnego”, Uniwersytet Pedagogiczny w Krakowie, 6-7 października 2008 r.

${ }^{3}$ GUS dopiero od niedawna prowadzi badania firm mikro, zatrudniających poniżej 10 osób. Uprzednio nie wyodrębniano tej grupy przedsiębiorstw.
} 
W Unii Europejskiej, podobnie jak w Polsce, dominują przedsiębiorstwa MŚP. Najwyższy wskaźnik liczby MŚP na 1000 mieszkańców jest w Czechach (90), w Portugalii (78), Grecji (75), natomiast najniższy w Niemczech, Rumunii i Słowacji. Wyniki badań dla Polski wskazują na dane liczbowe zbliżone do średniej unijnej (40). Według badań Ewy Balcerowicz (2008) łącznie w 27 krajach Unii Europejskiej jest zarejestrowanych i czynnie działa prawie 20 milionów firm, w tym w Polsce 1,4 miliona, co stanowi 7,2\% ogółu firm zarejestrowanych na obszarze UE. Podobnie jak w Polsce ponad 92\% tych przedsiębiorstw to przedsiębiorstwa zatrudniające do 9 osób. W krajach UE sektor MŚP otoczony jest szczególna opieką państwa i wdrożone są specjalne programy pomocowe, których celem jest podnoszenie konkurencyjności, wzrost innowacyjności oraz ułatwienie dostępu do najnowszych technologii. Szczególnym przykładem takiego działania jest Dania, gdzie podział przedsiębiorstw nie uwzględnia firm mikro-, a jedynie małe (do 49 osób) i średnie (od 50 do 99 osób). Według danych statystycznych, w Danii w roku 2004 działało czynnie 115000 małych firm oraz prawie 3600 firm zatrudniających od 50 do 249 pracowników. W Danii funkcjonuje program Innovation - Denmark 2007-2010 - duński rząd dla technologii i innowacyjności - plan wdrażania, którego głównymi założeniami są:

1. Być razem z krajami świata, które za najważniejsze uważają badania rozwojowe.

2. Duńskie przedsiębiorstwa powinny stać się najbardziej innowacyjnymi na świecie, a Dania powinna stać się krajem gdzie przedsiębiorstwa korzystają z najlepszych wyników badań różnych uczelni i ośrodków badawczych.

Innowacyjność firm duńskich kształtuje się następująco: innowacje produktowe wprowadziło $31 \%$ firm, innowacje procesowe $-30 \%$, innowacje organizacyjne - $58 \%$, a innowacje marketingowe $-20 \%$.

Integracja z Unią Europejską stanowiła istotny zwrot w gospodarce Polski, który najwyraźniej zaznaczył się w sektorze firm z grupy MŚP. Zmiany w przedsiębiorstwach, polegające na szybszym wdrażaniu innowacji w postaci nowych rozwiązań technicznych, technologicznych, organizacyjnych wpływają na rozwój i konkurencyjność tych przedsiębiorstw, konkurencyjność branży, a tym samym całej gospodarki w okresie integracji z gospodarką Unii Europejskiej i globalizacji (Bieliński 2005). Potencjał innowacyjny MŚP jest determinowany przez wewnętrzne cechy i umiejętności, dostęp do zewnętrznych źródeł wiedzy i finansowania innowacji.

Na wewnętrzny potencjał innowacyjny składa się:

- kadra (jej wiedza i doświadczenie, umiejętności i kwalifikacje oraz sposób zarządzania dostępnymi zasobami, zarządzanie informacją),

- badania i rozwój (wyodrębnione komórki $\mathrm{B}+\mathrm{R}$, prowadzone prace $\mathrm{B}+\mathrm{R}$, prace zlecane itp.),

- technologia (komputery i technologia ICT),

- posiadane maszyny i urządzenia, a także stopień nowoczesności maszyn i urządzeń).

Zewnętrzne źródła innowacji to przede wszystkim wyższe uczelnie i jednostki badawczo-rozwojowe, ale także firmy konkurencyjne czy odbiorcy/dostawcy. Badania GUS nie obejmują firm sektora MŚP, które stanowią zdecydowaną większość wśród polskich przedsiębiorstw. Nie biorą także pod uwagę potencjału innowacyjnego przedsiębiorstw, koncentrując się głównie na firmach dużych. Metodologia stosowana zarówno przez GUS, jak i EUROSTAT nie pozwala na jednoznaczne zidentyfikowanie rzeczywistej liczby innowacji i poziomu innowacyjności wszystkich przedsiębiorstw wchodzących w skład tzw. MŚP. Zatem zasób informacji w skali makroekonomicznej, służących porównaniu stopnia innowacyjności polskich i unijnych przedsiębiorstw, wymaga dopracowania i uściślenia. 


\section{BADANIA WŁASNE CZYNNIKÓW WPŁYWAJĄCYCH} NA POTENCJAŁ INNOWACYJNY FIRMY

Badania firm z grupy MŚP prowadzone były przez autorkę w latach 2006-2009 w ramach własnego programu badawczego, stanowiącego kontynuację problematyki innowacyjności przedsiębiorstw. Badaniem objęto 150 firm zatrudniających do 249 osób - z terenu województw: łódzkiego, mazowieckiego oraz kujawsko-pomorskiego. Wśród badanych 32\% stanowiły firmy z kapitałem zagranicznym, pozostałe to firmy prywatne z kapitałem polskim.

Struktura badanych firm:

$-48 \%$ - firmy usługowe,

$-52 \%$ - firmy produkcyjne.

Reprezentowane branże:

- 35\% - branża produkcyjna konstrukcje metalowe,

- 20\% - branża budowlana,

$-27 \%$ - branża motoryzacyjna,

$-5 \%$ - przemysł wydobywczy,

$-13 \%$ - usługi transportowe.

Zasadniczym celem badania było określenie elementów wpływających na potencjał innowacyjny przedsiębiorstwa MŚP oraz ustalenie ich wpływu na innowacyjność tych przedsiębiorstw. Ważnym celem było także zbadanie roli pracowników przedsiębiorstw $\mathrm{w}$ procesie innowacyjnym.

Przeprowadzone badania potwierdzają wcześniejsze wyniki, wskazujące na niski potencjał innowacyjny polskich MŚP w zakresie tworzenia innowacji o skali wyższej niż skala firmy. Jak wynika z badań jakościowych, w polskich MŚP działania odnoszące się do innowacji technicznych i technologicznych w skali regionu, branży lub wyższej mają charakter marginalny. Potwierdzają to wyniki badań ilościowych - aktywność innowacyjną deklaruje niespełna 30\% firm, przy czym zdecydowana większość z nich prowadzi działania innowacyjne jedynie w skali firmy. W wyniku przeprowadzonych badań wskazano na czynniki istotne, wpływające na innowacyjność i konkurencyjność firm. Bez względu na branżę do takich elementów należały tzw. kluczowe czynniki sukcesu firmy, które pokazuje ryc. 3 .

Respondenci (menedżerowie z firm MŚP) zgłaszali następujące obszary, w których występowały kluczowe dla nich czynniki sukcesu:

- zarządzanie kontaktami z klientem - umiejętność współpracy z klientami, wypełnianie ich oczekiwań w zakresie realizacji zamówień, zgłaszanie własnych koncepcji rozwiązań, np. w procesie produkcji lub realizacji dostaw,

- umiejętności pozyskiwania nowych klientów - zdolność wyszukiwania nowych, potencjalnych klientów, zgodnie z profilem działalności MŚP, umiejętność wskazywania kanałów informacyjnych oraz miejsc gdzie można spotkać potencjalnych klientów, np. podczas wystaw, targów, branżowych konferencji, w wyszukiwarkach internetowych etc.,

- zarządzanie informacją - umiejętność zbierania informacji, istotnych dla rozwoju firmy, informacji o otoczeniu, konkurentach, trendach rynkowych, poziomach cen, nowych technologiach,

- umiejętność uczenia się - gotowość do wykorzystywania wiedzy, podnoszenia kwalifikacji, uczenia się nowych zagadnień i technik, 
- umiejętność budowania relacji pomiędzy firmami MŚP - polskimi i zagranicznymi w sektorze, która przejawia się w otwartości wobec zapytań klientów i konkurentów, poszukiwaniu płaszczyzn współpracy i możliwości wykorzystania wzajemnych usług i synergii umiejętności,

- zdolność do tworzenia więzi typu sieciowego, gron - gotowość do różnorodnych i zmiennych form współpracy, których celem jest wzrost zasobów wiedzy.

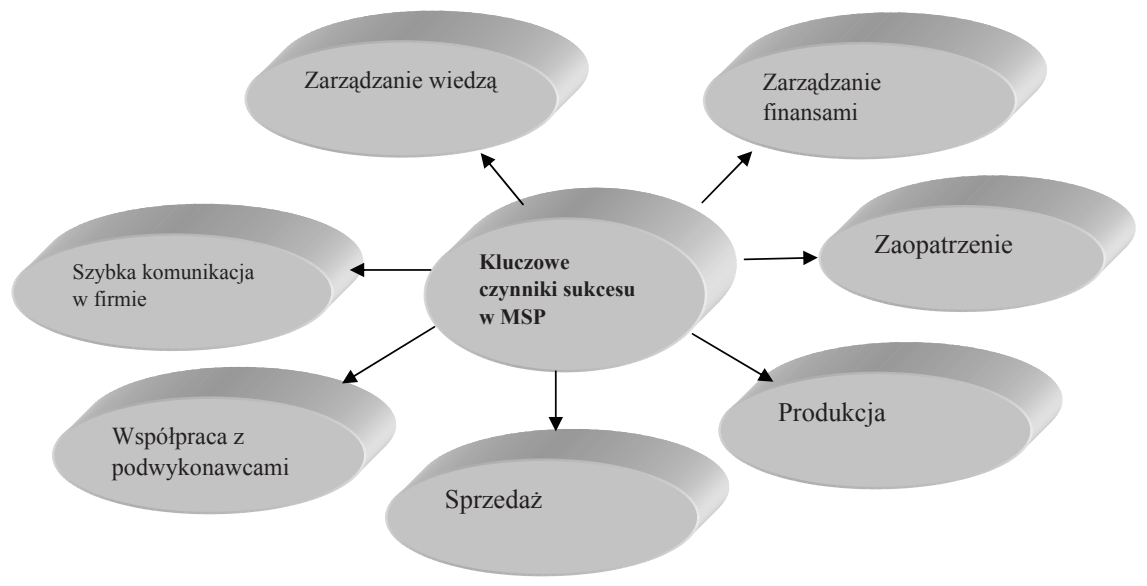

Ryc. 3. Kluczowe czynniki sukcesu w przedsiębiorstwach MŚP w branży konstrukcji stalowych

Źródło: Opracowanie własne na podstawie badań własnych w latach 2006-2009

Zarówno dobór badanych czynników sukcesu, jak i metodyka rozwiązywania problemów przy wprowadzaniu innowacji potwierdzają celowość stosowania wskazań heurystycznych czy technik CERMA (Antoszkiewicz 2008). Analiza uzyskanych danych pozwoliła na określenie znaczenia poszczególnych czynników sukcesu dla MŚP w badanych przedsiębiorstwach w branży konstrukcji stalowych. W tabeli 2 przedstawiono znaczenie kluczowych obszarów sukcesu dla przedsiębiorstw.

Tab. 2. Znaczenie kluczowych obszarów sukcesu dla przedsiębiorstw MŚP w branży konstrukcji stalowych

\begin{tabular}{|l|l|c|c|c|}
\hline \multirow{2}{*}{ Lp. } & \multirow{2}{*}{ Obszar sukcesu } & \multicolumn{3}{c|}{ Znaczenie obszaru dla firmy } \\
\cline { 3 - 5 } & & małe & średnie & duże \\
\hline 1 & Zarządzanie finansami & $0 \%$ & $18 \%$ & $82 \%$ \\
\hline 2 & Zakupy & $15 \%$ & $31 \%$ & $54 \%$ \\
\hline 3 & Produkcja & $5 \%$ & $27 \%$ & $68 \%$ \\
\hline 4 & Sprzedaż & $5 \%$ & $22 \%$ & $73 \%$ \\
\hline 5 & Współpraca z podwykonawcami & $37 \%$ & $7 \%$ & $56 \%$ \\
\hline 6 & Komunikacja w firmie & $30 \%$ & $31 \%$ & $39 \%$ \\
\hline 7 & Wiedza & $45 \%$ & $25 \%$ & $30 \%$ \\
\hline
\end{tabular}

Źródło: Opracowanie własne na podstawie badań własnych w latach 2006-2009 
Uzyskane wyniki pozwalają na wskazanie obszarów istotnych dla podnoszenia umiejętności wprowadzania innowacji (potencjału innowacyjnego) i tworzenia przyjaznych dla procesu innowacyjnego warunków funkcjonowania MŚP.

Efektywne działanie tworzonego systemu wsparcia innowacyjności w sektorze MŚP powinno być zgodne z celami rynkowymi przedsiębiorców. Niezbędne są badania poziomu innowacyjności polskich małych i średniej wielkości firm, ich potencjału innowacyjnego - jako czynnika decydującego o gotowości do wprowadzania innowacji ${ }^{4}$.

Prezentacja problematyki potencjału innowacyjnego przedsiębiorstwa, jego definiowania oraz pomiaru została poprzedzona badaniami własnymi przedsiębiorstw w kilku branżach, w tym w branży konstrukcji stalowych z grupy MŚP, wśród których znajdowały się przedsiębiorstwa polskie oraz firmy z kapitałem zagranicznym. Analiza wyników badań wskazuje, że pierwszym, podstawowym krokiem w stronę innowacyjności w polskich przedsiębiorstwach MŚP jest szersze wykorzystanie technologii informacyjno-telekomunikacyjnych, w tym Internetu. Pomimo że większość polskich firm dysponuje sprzętem komputerowym, zaś około 3/4 z nich posiada dostęp do Internetu, możliwości działania w światowej sieci nie są wykorzystywane. Polscy menedżerowie w wielu przypadkach nie wiedzą w jaki sposób efektywnie wykorzystać możliwości jakie daje informatyzacja i e-gospodarka. Tym samym ograniczają się do działania na dotychczasowych rynkach, oferując na nich te same, niezmienione produkty i usługi. Rzadko też korzystają z pomocy instytucji otoczenia biznesu, nie poszukują kontaktów z jednostkami sfery nauki, uważając, że odpowiedzialność za taki stan rzeczy spoczywa przede wszystkim na rządzie i instytucjach centralnych.

Proces kształtowania potencjału innowacyjnego przedsiębiorstwa MŚP ma charakter wieloetapowy - co zostało pokazane na ryc. 4. Kolejne etapy wiążą się z identyfikacją kluczowych umiejętności firmy, które można określić poprzez audyt technologiczny ${ }^{5}$. W warunkach małej firmy audyt powinien dotyczyć głównej działalności przedsiębiorstwa, odpowiedzieć na pytania: jakimi środkami technicznymi dysponuje mała firma, jakie umiejętności i zasoby wiedzy posiadaja jej pracownicy i właściciele. Pytania, na które odpowiada audyt technologiczny, powinny realistycznie określić, czy dana firma jest gotowa spełniać oczekiwania i standardy zgłaszane przez nabywców czy też są to jedynie deklaracje.

\footnotetext{
${ }^{4}$ Określenie metod badania potencjału innowacyjnego polskich firm sektora MŚP w branży konstrukcji stalowych było przedmiotem badań autorki w latach 2006-2009, m.in. szerzej omawianych w: D. Janczewska Model zarzqdzania innowacjami w przedsiębiorstwie - jako efekt transferu wiedzy ze sfery nauki do przemystu, [w:] Szkoty wyzsze kreatorem innowacji w gospodarce, red. R. Marcinkowski, Oficyna Wydawnicza Politechniki Warszawskiej, Warszawa 2009, s. 40.

5 Szerzej na temat audytu technologicznego zob. L. Białoń, D. Janczewska, Marketing innowacji, [w:] Tożsamość $i$ wizerunek marketingu w Polsce, red. R. Niestrój, PWE, Warszawa 2009, s. 202.
} 


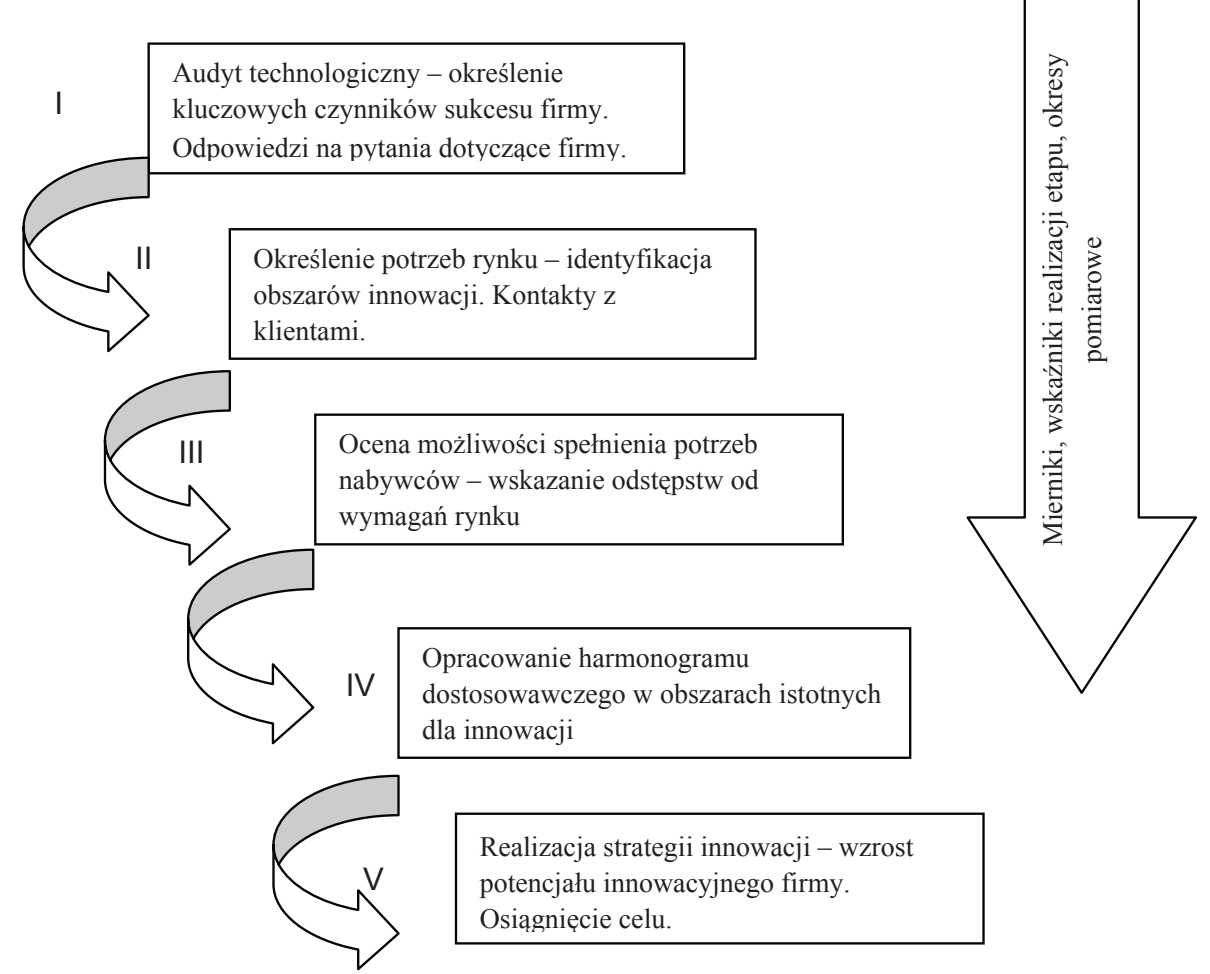

Ryc. 4. Proces kształtowania potencjału innowacyjnego w przedsiębiorstwie MŚP

Źródło: Opracowanie własne na podstawie badań własnych w latach 2006-2009

Efektem oczekiwanym procesu kształtowania potencjału innowacyjnego MŚP może być powstanie produktu innowacyjnego, zgodnego z oczekiwaniami nabywcy. W tabeli 3 zaprezentowano wynik badań nad powstawaniem innowacji w branży konstrukcji stalowych, w firmie MŚP. Celem realizacji projektu innowacyjnego było zapewnienie odpowiednich materiałów do wykonywania elementów wieży wiatrowej, na zlecenie nabywcy zagranicznego. Kolejne kroki w procesie wdrażania innowacji zostały zaplanowane i uzgodnione zarówno z klientem, jak i z przedsiębiorstwami kooperującymi i podwykonawczymi. Realizacja kolejnych etapów była możliwa do realizacji po osiągnięciu odpowiedniego na danym etapie potencjału innowacyjnego w poszczególnych komórkach organizacyjnych przedsiębiorstwa oraz w całej organizacji. Zastosowano metodę wewnętrznej wymiany informacji i szybkiego uczenia się poprzez częste narady i spotkania, w których uczestniczyli właściciele, menedżerowie, klienci oraz podwykonawcy i firmy współpracujące. Dodatkową formą uczenia się była wymiana informacji poprzez internet - co znacznie podniosło dynamikę przepływu wiedzy ${ }^{6}$.

\footnotetext{
${ }^{6}$ Dalsze badanie przedsiębiorstw z sektora konstrukcji stalowych pozwoli na poznanie czynników wpływających na dynamikę zmian innowacyjnych MŚP, ich struktury i charakteru. Dzięki badaniom możliwe będzie wskazanie czynników oraz grup zagadnień wpływających na proces innowacyjny w MŚP - ważnych z punktu widzenia samych przedsiębiorstw, z perspektywy branży, sektora i makrogospodarki.
} 


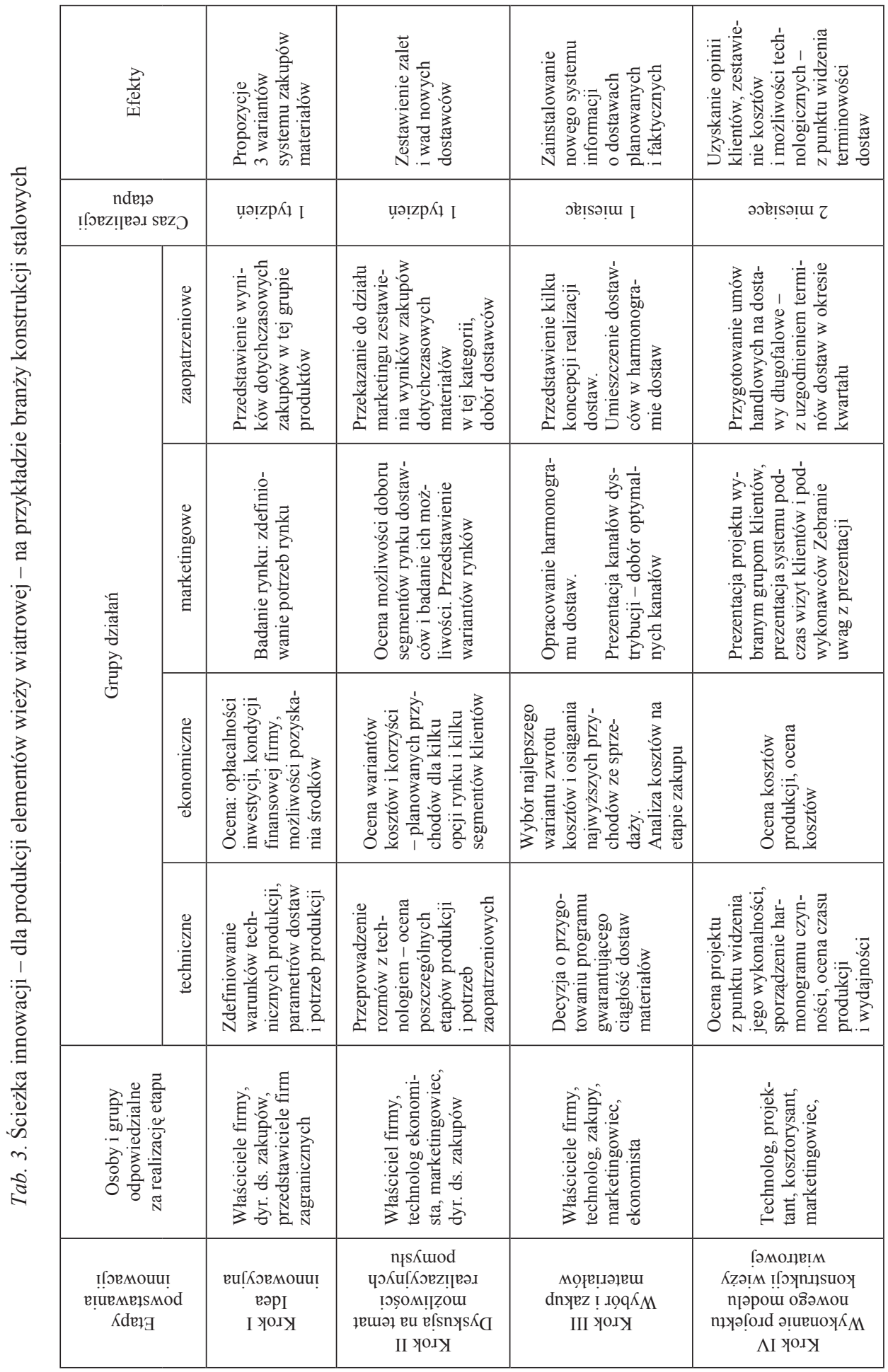




\begin{tabular}{|c|c|c|}
\hline 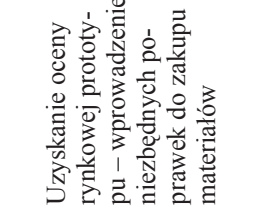 & 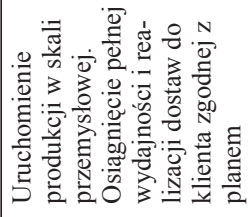 & 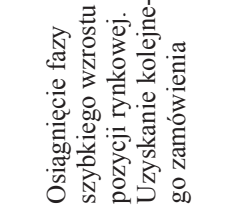 \\
\hline 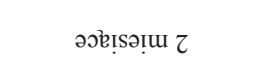 & 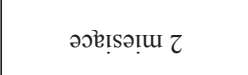 & 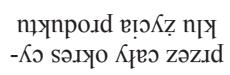 \\
\hline 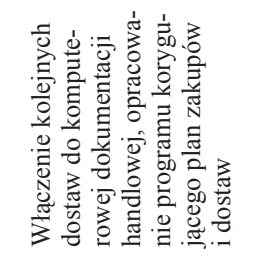 & 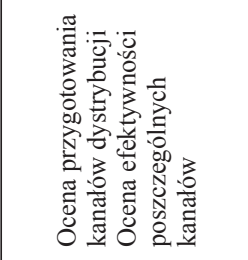 & 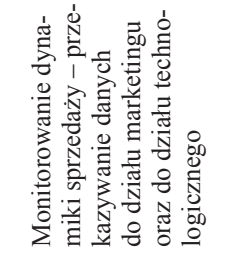 \\
\hline 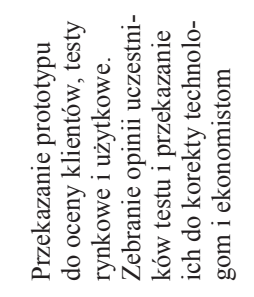 & 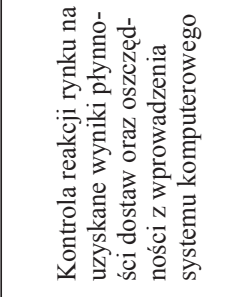 & 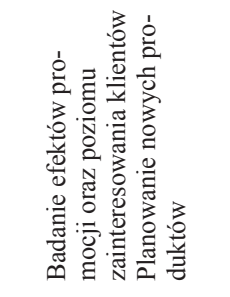 \\
\hline 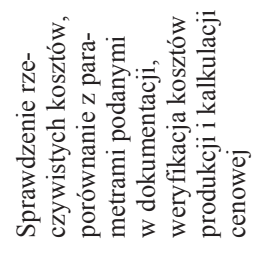 & 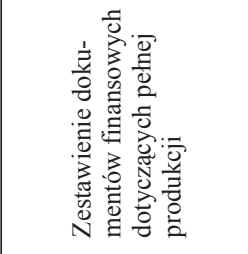 & 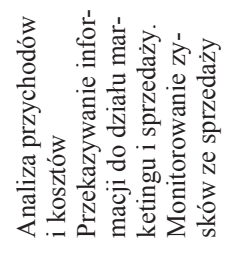 \\
\hline 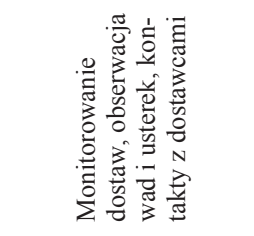 & 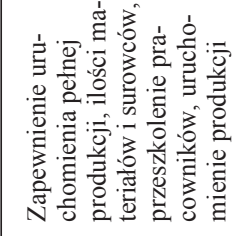 & 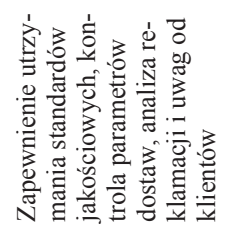 \\
\hline 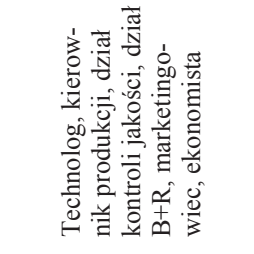 & 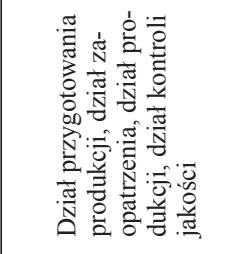 & 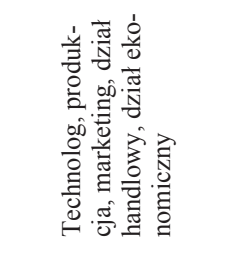 \\
\hline 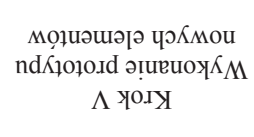 & 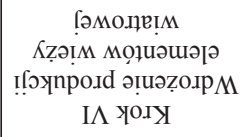 & 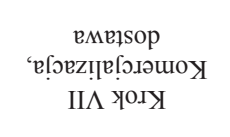 \\
\hline
\end{tabular}


Ścieżka innowacji pokazuje, że obecnie klienci coraz częściej przestają być biernymi nabywcami zadowalającymi się proponowaną ofertą handlową. Coraz częściej sami, czasami bezwiednie, uczestniczą w procesie kreowania i rozwoju produktów (wyrobów lub usług), które chcieliby później nabyć. Usatysfakcjonowany, ale wciąż wymagający nabywca stanowi więc niezwykle ważne ogniwo w zakresie kształtowania oferty handlowej przedsiębiorstw, a w rezultacie w kreowaniu innowacji. W tym przypadku właściwa identyfikacja jego potrzeb i nowych pomysłów staje się kluczowa w kontekście nowego podejścia do innowacji. Można stwierdzić, że zdolność dostrzegania nowych potrzeb konsumentów warunkuje proces poszukiwania nowych rozwiązań, odpowiadając jednocześnie na ich potrzeby. Konsumenci już się zorientowali, że znaleźli się na lepszej pozycji i że mają wielką siłę. Firmy muszą pogodzić się z tym, że zamiast kontrolować zachowanie klientów, jak było do tej pory, same znajdują się pod kontrolą. Strategie marketingowe stosowane w dużych przedsiębiorstwach oraz kanały dystrybucji nie zapewniają osiaggnięcia sukcesu rynkowego MŚP, gdyż przy ich pomocy trudno zidentyfikować i dotrzeć do docelowego konsumenta. Obecnie ważniejsze staje się wypracowanie nowych zasad istotnych dla kształtowania relacji pomiędzy klientem a firmą MŚP.

Jedną z barier w podejmowaniu działalności innowacyjnej w MŚP jest dostęp do informacji. Przykładem różnic w dostępie do informacji mogą być działania przygotowawcze do integracji z Unią Europejską. W okresie przedakcesyjnym, w którym firmy polskie podejmowały działania dostosowawcze do funkcjonowania w warunkach rynku europejskiego, większe możliwości zdobywania informacji miały przedsiębiorstwa duże, natomiast firmy średnie, małe i mikro nie dysponowały wystarczającymi informacjami na ten temat. Było to zjawisko niekorzystnie, wpływające na rozwój firm MŚP w tym okresie. Najpoważniejsze zagrożenie dla rozwoju firm MŚP stanowiły regulacje prawne - obowiązujące w wielu branżach (np. w branży spożywczej, transportowej) oraz przepisy dotyczące bezpieczeństwa produktów i oznakowania ce. Przedsiębiorstwa MŚP z krajów UE, posiadające informacje dotyczące regulacji, otoczenia rynkowego oraz wiedzę o rynku unijnym, dysponowały znaczną przewagą w stosunku do firm polskich.

W badanych firmach MŚP podejście do innowacji oraz sposób tworzenia innowacji $\mathrm{w}$ przedsiębiorstwach zmienia się wraz z pojawianiem się nowych koncepcji oraz metod, które pomagają w szybszym osiaganiu celów strategicznych przedsiębiorstwa oraz wpływają na proces kreowania innowacji. Zatem zdolność do kreowania innowacji staje się obecnie jednym z kluczowych czynników warunkujących zdolności i potencjał rozwojowy przedsiębiorstw. W wielu przedsiębiorstwach jako źródło innowacji wskazywano klientów, którzy prezentowali swoje własne koncepcje rozwiązań innowacyjnych konstrukcji stalowych. Następnie koncepcje te były przedmiotem dyskusji i narad ze specjalistami z dziedziny projektowania, technologii, zaopatrzenia w przedsiębiorstwie. Wspólne rozwiązanie stawało się punktem wyjścia do budowy prototypu, który był następnie akceptowany przez nabywcę lub modyfikowany. Prezentacja problematyki potencjału innowacyjnego przedsiębiorstwa w branży konstrukcji stalowych, działającego w warunkach konkurencji, wymagała jego zdefiniowania oraz pomiaru. Badania przedsiębiorstw w branży konstrukcji stalowych z grupy MŚP, wśród których znajdowały się przedsiębiorstwa polskie oraz firmy z kapitałem zagranicznym, wykazały możliwość podnoszenia konkurencyjności polskich przedsiębiorstw z grupy MŚP poprzez współpracę, wymianę informacji, uzgodnienia technologii i warunków prowadzenia produkcji oraz transferu wiedzy. Badania umożliwiły wyodrębnienie czynników wpływających na potencjał innowacyjny przedsiębiorstw z grupy MŚP, wśród których 
znalazły się: zasoby wewnętrzne i zewnętrzne w przedsiębiorstwie, gotowość do realizacji działań innowacyjnych, umiejętność efektywnego prowadzenia poszczególnych etapów procesu innowacyjnego oraz chłonność na wiedzę. W warunkach konkurencji na eurorynku, na którym zmienia się liczba uczestników rynku oraz dynamicznie rosną wymagania odbiorców, wyraźnie zwiększa się znaczenie procesów innowacyjnych w przedsiębiorstwach. W okresie integracji z Unią Europejską można wskazać na dodatkowe, nowe czynniki wpływające na powiększanie potencjału innowacyjnego przedsiębiorstwa MSP, takie jak: umiejętność budowania relacji pomiędzy firmami polskimi i zagranicznymi w sektorze oraz zdolność do tworzenia więzi typu sieciowego, gron oraz gotowość do różnorodnych i zmiennych form współpracy, których celem jest przepływ wiedzy, a następnie rozwój jej zasobów.

Przedsiębiorstwa z grupy MŚP stanowią większość przedsiębiorstw funkcjonujących w polskiej rzeczywistości gospodarczej. Zmiany w przedsiębiorstwach, polegające na szybszym wdrażaniu innowacji w postaci nowych rozwiązań technicznych, technologicznych, organizacyjnych etc. wpływają na rozwój i konkurencyjność tych przedsiębiorstw, konkurencyjność branży, a tym samym całej gospodarki w okresie integracji z gospodarką Unii Europejskiej i globalizacji. Zatem poznanie przyczyn dynamiki zmian innowacyjnych oraz ich przebiegu w przedsiębiorstwach MŚP pozwoli na wskazanie czynników wpływających na doskonalenie procesu innowacyjnego - ważnych zarówno z punktu widzenia przedsiębiorstw, jak i z punktu widzenia branży, sektora i całej gospodarki.

\section{Literatura}

Antoszkiewicz A.D., 2008, Innowacje w firmie, praktyczne metody wprowadzania zmian, POLTEXT, Warszawa

Balcerowicz E., 2009, Mikroprzedsiębiorstwa w Polsce na tle Unii Europejskiej, [w:] A. Żołnierski (red.), Raport o stanie sektora matych i średnich przedsiębiorstw w Polsce w latach 2007-2008, PARP, Warszawa

Białoń L., Janczewska D., 2004, Bezpośrednie Inwestycje Zagraniczne w Polsce - marketingowe metody oceny z perspektywy sektora, WSM SIG, Warszawa

Białoń L., Janczewska D., 2009, Uwarunkowania strategii innowacji w organizacjach, Postępy Techniki Przetwórstwa Spożywczego - Technological Progress in Food Processing, No 1, Tom $19 / 34$

Bieliński J. (red.), 2005, Konkurencyjność przedsiębiorstw w świetle Strategii Lizbońskiej, CeDeWu, Warszawa

Innovation in Denmark 2007-2010, 2006, Danish Agency of Technology and Innovation, Denmark

Sosnowska A., Łobejko S., Kłopotek A., 2000, Zarzqdzanie firmq innowacyjnq, Difin, Warszawa

To increase the innovative potential of SMEs, 2005, Commission Officials, EU Report, Brussels

Viturka M., 2004, Innovative Potential Regional Evaluation in the Czech Republic, Masaryk University, Praha

Wojnicka E., Klimczak P., 2006, Stan sektora MŚP w 2004 roku, tendencje rozwojowe w latach 19942004, PARP, Warszawa

Żołnierski A., 2009, Raport o stanie sektora małych $i$ średnich przedsiębiorstw $w$ Polsce $w$ latach 2007-2008, PARP, Warszawa 


\section{Process of forming the innovative potential in companies of SMEs in steel constructions sector in competitive conditions on the $\mathrm{EU}$ market}

The SMEs companies form the biggest part of all companies carrying out production in the Polish economic reality. The changes in enterprises, such as faster initiation of innovations or new technical, technological, and organization solutions, etc. were involved in the development and competitiveness of these companies and competitiveness of the whole branch - and in the same way, in the whole economy at the time of integration with the EU economy and globalization. Then, the knowledge about reasons and dynamics and structure of innovative changes in enterprises will provide the possibility to show the groups of factors involved in the innovative process, which is important for the enterprises and for the branch.

The presentation of innovative potential as definitions and measurement was based on the research of a group of SMEs, consisting of Polish and foreign enterprises. The main goal of the research was to explain the reason for FDI in the Polish branch of steel constructions and the influence of FDI on innovativeness of the Polish SMEs.

The obtained results allowed to define the factors with high influence coefficient for innovative potential in steel construction branch as inside and outside values, the readiness to realize the innovative activity, and skills of effective realization of all parts of the innovative process and knowledge absorption. In conditions of competitiveness on the EU market - where dynamic changes of quantity of participants and increase in the expectation of clients are observed - there are clearly growing meanings of the innovative process. In the present time of EU integration, there are quite new, additional factors in Polish SMEs, such as skills in building the relation between SMEs and abilities to create nets and clusters, and readiness for many different and changing forms of cooperation and growth at the level of knowledge.

Dr inż. Danuta Janczewska

Społeczna Wyższa Szkoła Przedsiębiorczości i Zarządzania w Łodzi

Wydział Zarządzania

e-mail: janczewska@republika.pl 